\title{
Assessment of Wildlife Hunting Activities in Ido Local Government Area, Oyo State Nigeria
}

\section{${ }^{1}$ LAYADE, KT; ${ }^{2}$ LAYADE, AA; ${ }^{3}$ KEHINDE, OJ; ${ }^{4}$ ALAYE, SA; JAYEOBA, WA}

\author{
${ }^{1 *}$ Onigambari Research Station, Forestry Research Institute of Nigeria, Ibadan, Nigeria \\ ${ }^{2}$ National Horticultural Research Institute, Ibadan, Oyo State, Nigeria \\ ${ }^{3}$ Federal College of Forestry, Ibadan, Oyo State, Nigeria. \\ ${ }^{4}$ Federal College of Wildlife Management, New Bussa, Niger State, Nigeria. \\ ${ }^{5}$ Federal College of Forestry Mechanization, Afaka Kaduna, Nigeria \\ *Corresponding Author Email: toplay408@gmail.com
}

\begin{abstract}
The study was conducted to assess hunting activities in Ido Local Government Area, Oyo State, Nigeria. A well-structured questionnaire was administered to obtain information from fifty hunters using a simple random sampling technique. Data were analyzed using descriptive statistics. The result showed that $96 \%$ of hunters in the study area were men. Most of the respondents were married (84\%) and within the age bracket of 31 and 50 years $(48 \%)$. About $34 \%$ and $40 \%$ of respondents had primary and secondary education respectively while $13 \%$ had no formal education. They had between 20 and 29 years' experience in wild animal hunting. Sixty-eight percent of the hunters in the study area engaged in part-time hunting while $32 \%$ were full-time hunters. The study further revealed that the hunters engaged in hunting for financial gain $(64 \%)$, leisure $(34 \%)$ and family tradition (38\%). About ten types of species of wildlife animals were commonly killed by the hunters, and the animals were sold within the community market (42\%), outside the community market (32\%) and to visiting bushmeat marketers $(26 \%)$. The study therefore recommends a policy that will control hunting activities in the study area, knowing that animal hunting serves as another source of livelihood to the hunters.
\end{abstract}

\section{DOI: https://dx.doi.org/10.4314/jasem.v25i3.16}

Copyright: Copyright (C) 2021 Layade et al. This is an open access article distributed under the Creative Commons Attribution License (CCL), which permits unrestricted use, distribution, and reproduction in any medium, provided the original work is properly cited.

Dates: Received: 12 December 2020; Revised: 26 January 2021; Accepted: 12 February 2021

Keywords: Hunters, wildlife, bushmeat, community market, occupation

Wildlife hunting is an important aspect of life in rural areas in Nigeria. Animals from the forest serve as source of animal protein to hunters' family and those that relish bushmeat. It is also a good choice of minerals and vitamins, and the meat is sometimes recommended by medical doctors to improve patient's health conditions (Bifarin et al, 2008).

The sale of animals killed from the wild also provides income for hunters and many supplement their livelihood by hunting (Ntiamoa-Baidu, 1997; Falola et al, 2015, Babalola and Oladipupo, 2018). Although hunting in most of the rural areas in Nigeria are illegal, yet they are able make a living, especially during dry season.

This study was carried out to assess the activities of wild animal hunters in Ido Local Government Area of Oyo State, Nigeria. The specific objectives include: describe the socioeconomic characteristics of the hunters; examine the reasons for engaging in hunting; identify the types of wild animals killed by hunters in the study area.

*Corresponding Author Email: toplay408@gmail.com

\section{MATERIALS AND METHODS}

Study Area: The research was conducted Ido Local Government Area, Oyo state, Nigeria. The Local Government is one of the Oldest Local Government in the State located in Southern part with an area of 986 square kilometers and lies at latitude $7^{\circ} 30^{\prime} 44.50^{\prime \prime} \mathrm{N}$ and longitude $3^{\circ} 47^{\prime} 35.00^{\prime \prime E}$. It has an annual rainfall ranges from $100 \mathrm{~mm}$ to $1800 \mathrm{~mm}$ and average daily temperature of $24.1^{\circ} \mathrm{C}$ and $28^{\circ} \mathrm{C}$. The population of Ido was 103,261 as at 2006 census (NPC, 2006). The target population for this study were hunters.

Sampling Technique and Data Collection: A random sampling technique was adopted to select the respondents for the study. The totalof fifty hunters were selected from the list provided by the Egbe Oluode Ilu Ido, Ido Local Government Area, Oyo State, Nigeria. Primary data were collected through the use of structured questionnaire administered to the respondents complemented with oral interview. Information obtained from the respondents include: socio-economic profile (sex, age, marital status, years and level of education), 
information on hunting activities (years of experience in hunting, tools, selling prices of animals caught etc.) and challenges encountered.

Data Analysis: Data were analyzed using descriptive and inferential statistics. Descriptive statistics (frequency, percentage and mean) were employed to describe socio-economic profile of the respondents and identify the constraints to hunting activities.

\section{RESULTS AND DISCUSSION}

Socio-economic Characteristics of Respondents: Wildlife hunting in the study area is done by both male and female. However, male hunters $(96 \%)$ are more than female (4\%), indicating that animal hunting is predominantly male activity in the study area. Women and children also play a significant role in the hunting and collection of wild resources to feed the household in Africa (Ntiamoa-Baidu, 1997). Most of the respondents were married $(84 \%)$ and within the age bracket of 31 and 50 years $(48 \%)$, showing that they were mature and have responsibilities. Furthermore, $34 \%$ and $40 \%$ of the respondents had primary and secondary education respectively while $13 \%$ had no formal education. On the basis of years of experience in hunting, $36 \%$ have spent 20-29 years, $26 \%$ spent $40-49$ years and $10 \%$ have spent between 10-19 years. This is an indication that the respondents have been long in animal hunting (Table 1). The income realized from bushmeat hunting ranges from $¥ 11,000$ to $\$ 19,000$ (52\%), 20,000 to $\$ 29,000$ (20\%), $\$ 30,000$ to $\$ 39,000$ (18\%) and only $2 \%$ made above 49,000 monthly.

Table 1: Socio-economic characteristics of hunters in the study area

\begin{tabular}{|c|c|c|c|}
\hline Characteristics & & Frequency & Percentage \\
\hline \multirow[t]{2}{*}{ Sex } & Male & 48 & 96.0 \\
\hline & Female & 2 & 4.0 \\
\hline \multirow[t]{2}{*}{ Marital status } & Single & 8 & 16.0 \\
\hline & Married & 42 & 84.0 \\
\hline \multirow[t]{8}{*}{ Age (years) } & $\leq 20$ & 2 & 4.0 \\
\hline & $21-30$ & 5 & 10.0 \\
\hline & $31-40$ & 18 & 36.0 \\
\hline & $41-50$ & 6 & 12.0 \\
\hline & $51-60$ & 10 & 20.0 \\
\hline & $61-70$ & 2 & 4.0 \\
\hline & $>70$ & 7 & 14.0 \\
\hline & Average age $=48$ years & & \\
\hline \multirow{3}{*}{$\begin{array}{l}\text { Level of } \\
\text { education }\end{array}$} & No formal education & 13 & 26.0 \\
\hline & Primary education & 17 & 34.0 \\
\hline & Secondary education & 20 & 40.0 \\
\hline \multirow[t]{4}{*}{ Household size } & $1-5$ & 27 & 54.0 \\
\hline & $6-10$ & 20 & 40.0 \\
\hline & $11-15$ & 3 & 6.0 \\
\hline & Average household size $=6$ & & \\
\hline \multirow{8}{*}{$\begin{array}{l}\text { Hunting } \\
\text { Experience } \\
\text { (years) }\end{array}$} & $<10$ & 4 & 8.0 \\
\hline & $10-19$ & 5 & 10.0 \\
\hline & $20-29$ & 18 & 36.0 \\
\hline & $30-39$ & 1 & 2.0 \\
\hline & $40-49$ & 13 & 26.0 \\
\hline & $50-59$ & 7 & 14.0 \\
\hline & No response & 2 & 4.0 \\
\hline & Average year of experience $=28$ & & \\
\hline \multicolumn{4}{|l|}{ Income } \\
\hline & Less than 10000 & 3 & 6.0 \\
\hline & $11000-19000$ & 26 & 52.0 \\
\hline & $20000-29000$ & 10 & 20.0 \\
\hline & $30000-39000$ & 9 & 18.0 \\
\hline & $40000-49000$ & 1 & 2.0 \\
\hline & Above 49000 & 1 & 2.0 \\
\hline
\end{tabular}

Source: Field survey, 2019.

Information on hunting activities: In table 2, most of the respondents engaged in hunting as part-time job $(68 \%)$. This is an indication that the local hunter don't often depend on animal hunting alone for their livelihood, they combine it with other jobs. Other occupations of the respondents were crop farming (70\%), commercial motorcyclists $(26 \%)$ and trading (4\%). Moreover, sixty percent of the respondents 
received training in hunting either from their father $(42 \%)$ or other hunters in the community $(50 \%)$. The hunters in the study area engage in hunting for financial gain, and also it is a family tradition for some respondents. This result corroborates the findings of Akinyemi (2018) who stated that wild animals hunting is one of the oldest professions handed down from forefathers to descendants. On the basis of membership association, all the respondents belong to hunters' association called Egbe Oluode Ilu Ido a subgroup of Hunters Association of Nigeria, Oyo
State Chapter. Their membership of hunting association may be due to the fact that they derived some benefits from it (Layade and Layade, 2020). The association serves as a platform for older ones to share experience and knowledge with the younger hunters through the association activities. The study further revealed that the wildlife animals killed by the hunters were sold within the community market $(42 \%)$, outside the community market $(32 \%)$ and to visiting bushmeat marketers $(26 \%)$.

Table 2: Information on hunting activities

\begin{tabular}{|c|c|c|c|}
\hline Variable & & Frequency & Percentage \\
\hline \multirow{2}{*}{$\begin{array}{l}\text { Mode of engagement } \\
\text { in hunting }\end{array}$} & Full-time & 16 & 32.0 \\
\hline & Part-time & 34 & 68.0 \\
\hline \multirow[t]{3}{*}{ Other occupation } & Crop farming & 35 & 70.0 \\
\hline & Commercial motorcyclist & 13 & 26.0 \\
\hline & Trading & 2 & 4.0 \\
\hline \multirow[t]{2}{*}{ Hunting training } & Received training & 30 & 60.0 \\
\hline & Not receive trainings & 20 & 40.0 \\
\hline \multirow[t]{3}{*}{ Mentoring in hunting } & Father & 21 & 42.0 \\
\hline & Uncle & 4 & 8.0 \\
\hline & Others & 25 & 50.0 \\
\hline \multirow[t]{4}{*}{$\begin{array}{l}{ }^{a} \text { Reason for hunting } \\
\text { game }\end{array}$} & $\begin{array}{l}\text { Financial reward to support } \\
\text { family }\end{array}$ & 32 & 64.0 \\
\hline & Leisure & 17 & 34.0 \\
\hline & Due to hardship & 9 & 18.0 \\
\hline & Family tradition & 19 & 38.0 \\
\hline \multirow{2}{*}{$\begin{array}{l}\text { Membership of } \\
\text { association }\end{array}$} & Member & 50 & 100.0 \\
\hline & Non-member & - & - \\
\hline \multirow{3}{*}{$\begin{array}{l}\text { Benefits derive from } \\
\text { association }\end{array}$} & Welfare & 27 & 54.0 \\
\hline & Socialization & 9 & 18.0 \\
\hline & $\begin{array}{l}\text { Sharing of Knowledge and } \\
\text { experience }\end{array}$ & 14 & 28.0 \\
\hline \multirow[t]{4}{*}{$\begin{array}{l}{ }^{a} \text { Market where } \\
\text { hunters sell the game }\end{array}$} & & & \\
\hline & Community market & 21 & 42.0 \\
\hline & Market outside community & 16 & 32.0 \\
\hline & Visiting bushmeat marketers & 13 & 26.0 \\
\hline
\end{tabular}

Table 3: Distribution of types of wild animals killed by hunters in the study area

\begin{tabular}{lll}
\hline COMMON NAME & SCIENTIFIC NAME & LOCAL NAME \\
\hline Grasscutter & Thryonomys swinderianus & Ewuju/Oya \\
Antelope & Hippotragus equines & Esuro \\
Giant rat & Crycetomys gambianus & Okete \\
Common gray Duiker & Cephalophus spp. & Etu \\
African black snake & Dendroaspis polylepis & Sebe \\
Cobra & Naja nivae & Oka \\
Pangolin & Manis spp. & Aaka \\
Squirrel & Protoxeryx spp. & Okere \\
Rabbit & Orytolagus cuniculus & Ehoro \\
Bushbuck & Tragelaphus scriptus & Igala \\
\hline & Source: Field survey, 2019.
\end{tabular}

Types of wild animals killed by hunters in the study area: The types of species of wildlife animals commonly killed by the hunters in the study area were presented in table 3 . The animals hunted were grasscutter, antelope, giant rat, gray duiker,
African black snake, pangolin, squirrel, rabbit and bush buck. According to the hunters, grasscutter (Thryonomys swinderianus) is predominant among the animals (Table 3). Among the greater number of mammalian species found in the study carried 
out by Halidu, 2019; Tee et al, 2012, Friant et al, 2015, were grasscutter, giant rat and duiker.

Conclusion: The study assessed activities of wildlife hunters in Ido Local Governent, Oyo State, Nigeria. Wildlife hunting was a male-dominating activities in the study area. It was shown from the study that hunting was a part-time profession as most of the hunters combined it with other jobs. Hunting in the study area is mostly a family tradition as many of the hunters inherited it and received further training from their parents or uncles. Ten wild animals were identified as commonly killed in the area.

\section{REFERENCES}

Akinyemi, IG (2018). Assessment of wildlife hunting methods in two ecological zones in Nigeria. Sch. J. Agric. Vet. Sci. 5(12):664-668

Babalola, FD; Oladipupo, AD (2018). Evaluation of factors associated with bushmeat marketing in Igbomina District of Kwara State, Nigeria. J. Forest. Res. Manage. 15(1):3-50.

Bifarin, JO; Ajibola, ME; Fadiyimu, AA (2008). Analysis of marketing bushmeat in Idanre Local Government Area of Ondo State, Nigeria. Afr. J. Agric. Rese. 3(10):667-671.

Falola, A; Ajewole, OO; Ajibade, TB; Abdul, RM (2015). Assessment of welfare status of Bushmeat traders in post-ebola era in Kwara State, Nigeria. $J$. Multidisc. Stud. 4(2):1-26.
Friant S; Paige SB; Goldberg TL (2015). Drivers of Bushmeat Hunting and Perceptions of Zoonoses in Nigerian Hunting Communities. PLoS Negl. Trop. Dise. 9(5):1-16.

Halidu, KS (2019). Assessment of bushmeat sale and its implication on wildlife conservation in Old Oyo National Park, Nigeria. World News Nat. Sci. 23(2019):266-275.

Layade, KT; Layade, AA (2020). Assessment of bushmeat marketing in Oluyole Local Government, Oyo. J. Rese. Forest. Wild. Environ. 12(3):132-137.

National Population Census (NPC). 2006. National Bureau of Statistics Official Gazette. Abuja. 10 December 2014.

Ntiamoa-Baidu, Y (1997). Wildlife and food security in Africa. FAO Conservation guide, 33.

Tee TN; Ikpa TF; Tortange; V (2012). Bush meat trade in Markudi Metropolis; implications for the Conservation of wildlife in Nigeria. J. Appl. Biosci. 52: 3704-3715 